\title{
The application of GIS in railway heritage management: the case of Yunnan-Vietnam Railway
}

\author{
Kun Sang ${ }^{\mathrm{a},}$, Silvia E. Piovan ${ }^{\mathrm{a}}$ \\ ${ }^{a}$ Department of Historical and Geographic Sciences and the Ancient World, \\ kun.sang@phd.unipd.it, silvia.piovan@unipd.it \\ * Corresponding author
}

\begin{abstract}
Railways were a key mode of transporting goods and people for industrial and urban development in the late modern age. Their special part in economic growth comes with their role in the development of cultural heritage along their pathways. However, because of competing urban construction, many railway heritages are in danger, such as the Yunnan-Vietnam Railway (YVR) in China, an important international narrow-gauge railway built in 1901, acknowledged as a railway heritage in 2018. As a typical linear heritage, the railway integrates both the natural and cultural landscapes, related to the large spatial extent and complex composition of single heritage elements. Geographic Information Systems (GIS) offer a great support in the investigation, assessment, and management of railway heritage. In this research, the huge cultural heritage related to the YVR was studied using a combined geo-historical and GIS approach. This paper aims to 1) give a brief review of the current status of the application of GIS on linear railway heritages studies, including heritage resources surveys, spatial analysis, thematic mapping and public service, 2) introduce the case study of the Yunnan-Vietnam Railway, and 3) present a geodatabase design for the Yunnan-Vietnam Railway heritage management.
\end{abstract}

Keywords: Geographic Information System, railway heritage, Yunnan-Vietnam Railway, cartography

\section{Introduction}

Railway heritage is a typical cultural route reflecting the integrity of nature and human landscape. Railway heritage involves both natural and cultural elements that embody the same geo-historical background related to the railway itself. For its social and economic functions in history, the railway is of great importance to enhance the cultural identity and to promote regional sustainable development (Zhang, 2017). It can be also a green corridor, a crucial means for integrating separated monuments and heritage sites (Howard, 2003), strengthening regional exchanges and communications, preventing the landscape and ecological fragmentation (Wang, 2011). As a symbol of modernity and a carrier of industrial-technological achievements, the railway heritage offers both landscape and heritage experiences, which meet the public needs of nostalgia for steam age and the memory of childhood (Dann, 1994; Coulls, 1999).
In Europe, the $\mathrm{UNECTO}^{1}$ has acknowledged 78 railway heritages whose average length is nearly $14 \mathrm{~km}$. In China, seven railways are in the national industrial heritage list, among which the Chinese Eastern Railway $(2426 \mathrm{~km})$ is the longest. In fact, the seven railways on the Chinese National Industrial Heritage list have some common characteristics: 1) the large spatial extent of territory, 2) dynamic environment, 3) complex composition of heritage elements, and 4) a massive amount of spatial data related to the heritage. This complexity makes the railway as a long linear heritage, hard to manage, requiring comprehensive coordination of all the relevant information (Tang, 2013).

The Geographic Information System (GIS) is recognized widely as a powerful tool for supporting design, planning and decision-making process in land resource management, environmental assessment, urban planning, and many other contexts. For the advantages in data management, spatial analysis, and user-friendly information interpretation, GIS has been used in

\footnotetext{
${ }^{1}$ Union des exploitants de chemins de fer touristiques et de musées
} 
conservation of cultural heritage since the 1990s. The development and the integrated use of GIS, remote sensing and Global Positioning System (GPS) within archaeological and historical contexts became of great importance in the early 2000s especially when the concept of "Historical GIS" (HGIS) was developed (Knowles, 2000; Gregory \& Healey, 2007; Knowles, 2008; Knowles et al., 2008 ; Bailey \& Schick, 2009). As Knowles's (2013) definition, HGIS became a digital approach used to "study the past spatially".

Nowadays, many scholars apply GIS and HGIS in processing, analyzing and mapping large-scale heritages, such as heritage corridors and cultural routes, which received widespread concerns also from the whole society. GIS offers great potential in the management of railway heritage, exploring the relationships among the railway and the natural and human environment. These relationships can be better understood by performing spatial, 3D and network analysis using diverse spatial layers such as hydrology, surface, slope, land cover and heritage database.

The worldwide experience of GIS application in cultural heritage is reviewed by many scholars (e.g. Petrescu 2007). GIS is also used for predictive modeling of archaeological site location (e.g.: Historic Landscape Characterisation (HLC). The combination of landscape studies and GIS tools stimulates the independent development of landscape archaeology. Cultural Resource Management based on a geodatabase and the spatial analysis for landscape features, spatial processing, and viewsheds are some main applications of GIS (Zhang, 2010). The historical GIS (HGIS) approach was also applied to build the database of historical railways in Europe, for the analysis of their pattern evolution (Morillas-Torné, 2012), explaining the relationship between urbanization and railway (Atack et al., 2010).

For example, the heritage system of the Chinese Eastern Railway uses GIS combined with GPS and remote sensing and matrix laboratory (MATLAB) as the platform, combined the Minimum Cumulative Resistance Model and the analytic hierarchy process to build a spatial pattern of heritage corridors of different levels (Tang, 2017). For the Tea Horse Road, a structured database is designed with layers of data, management, service, and application (Feng, 2016). Also, the suitability analysis with GIS is discussed in the case of the Zhangzhou Ancient Post Road (Zhan \& Guo, 2015).

This article presents the Yunnan-Vietnam railway as an example of the potential of applying GIS to the management of railway heritage sites. Reviewing some existing projects and research, this research proposes to design and populate a geodatabase for the management of the abundant and complex network of geo-historical data and heritage sites along the YVR route.

\section{Yunnan-Vietnam Railway}

The Yunnan-Vietnam Railway $\left(\mathrm{CFY}^{2}\right.$ or YVR) is a relevant narrow-gauge railway in China, constructed by France in 1903-1910 between the Yunnan province of China and the Tonkin region of Indochina ${ }^{3}$. The Chinese section has a length of $389 \mathrm{~km}$, while in Vietnam it extends $466 \mathrm{~km}$. Due to physical geographical characteristics that made the building of the railway very difficult, the YVR was acclaimed as a technological miracle in modern history. In order to complete this project, about 60,000 workers participated in the construction, which consumed nearly 8,000 animals and 50,000 tons of rails. More than 12,000 workers and 80 French engineers died in construction. (Archive of Yunnan, 2014).

Known as the historical corridor between Indochina and southwestern China, it was built according to the development plan proposed by the governor of French Indochina - Paul Doumer. This railway is one of the earliest built railways, the first international railway in China, as well as the longest one-meter railway. It links rich cultural heritage, industrial heritage and landscape resources of Yunnan Province and North Vietnam. Some of its remains are recognized as national cultural heritage sites, such as the famous Namti Braidge. Through the construction of the YVR, Yunnan province was opened to the world, bringing the modernity and industrialization to this region of south-eastern Asia (Che, 2006).

The historical, social, economical, cultural, political and technological meanings of the YVR give great heritage value and make it a cultural symbol in the daily life of local people and in tourism of the area (Zhang, 2013). The Yunnan government has developed three touristic routes with a total length of $70 \mathrm{~km}$ (illustrated in Figure 1). Relevant stakeholders such as local authorities of Hekou, Kaiyuan and some other private associations all hope to develop the YVR scenic resources to improve the railway tourism development. For example, there are some cultural tourism projects under development in Kunming, Kaiyuan and Bisezhai ${ }^{4}$ (Chen, 2011).

Throughout the history of nearly 110 years, the railway still functions well for transportation but, despite some propositions of improving the tourism along the railway corridor, the protection and the valorisation of the YVR heritage is not that optimistic. The main challenges that the railway is facing are different. First, the presence of the railway in heavy-growing urban contexts generates many territorial conflicts, such as the urban areas in Kunming and Hanoi. Second, some routes that belonged

\footnotetext{
${ }^{2}$ Chemin de fer de l'Indochine et du Yunnan

${ }^{3}$ French Indochina (1887-1945), Tonkin is the northern part of Vietnam in Indochina.

${ }^{4}$ Main stations along the railway
} 
to the historic railway have been abandoned: an example is the segment of the branch near Mengzi (shown in Figure 1). Third, the high cost for the maintenance of the railway and related structures is challenging for the local authorities that have also many difficulties in coordination due to the complicated administrative divisions. Furthermore, some historical sites, such as some French-style stations have already been destroyed as they were no recognized as valuable. Last, but not least, the ordinary people lack the understanding of the meaning of railway heritage and its redevelopment.

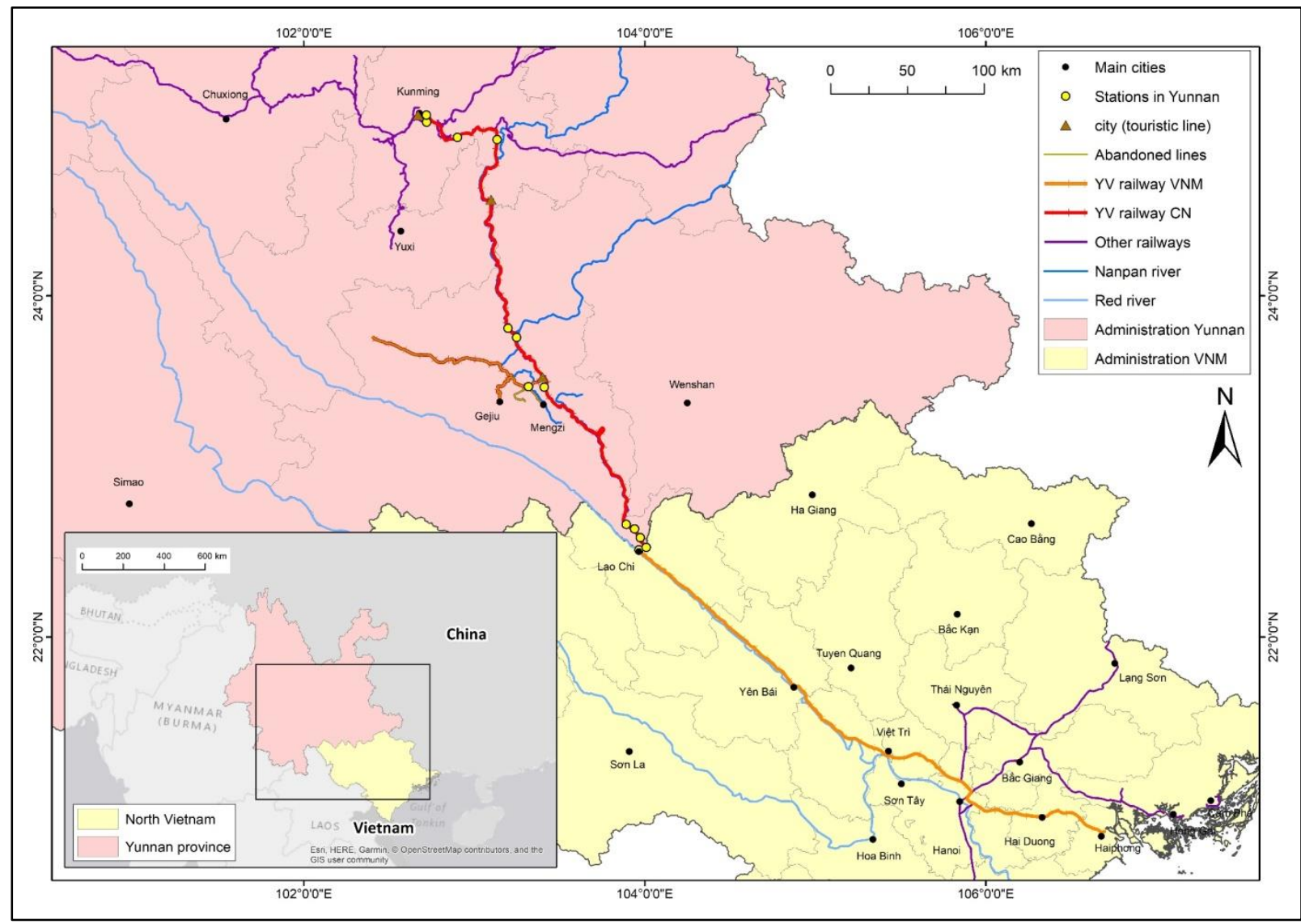

Figure 1. Location of the Yunnan-Vietnam Railway.

There have been various research studies for the YVR, from the point of views of history and modernization (Che, 2006), tourism (Fan, 2011), architecture (Fan, 2008) and the possibility of building a heritage corridor (Luo, 2012). However, GIS and HGIS application have been seldom applied in the study of this railway (Zhang, et al., 2010). In order to help in solving these problems the creation of a heritage GIS geodatabase seems to be essential for further analysis, planning, and tourism management.

\section{A Geodatabase for the YVR Heritage}

\subsection{Design of the Geodatabase}

\subsubsection{Objectives}

A geodatabase is a standard relational database schema created and owned by ESRI, in the ArcGIS platform. It can effectively define and express spatial entities, systematize their constraint relationship, and make the defined model close as its state in the real world. A geodatabase supports unified management of geographic data in multiple formats, allowing multiple users to access and edit the same geographic area simultaneously. A geodatabase design for the heritage of YVR can link the isolated heritage assets and put them in relation with the characteristics of the natural and human environment, helping in the analysis and mapping processes. It overcomes the shortcomings of the traditional heritage catalog, containing various geospatial layers of heritage elements, including the route itself and present-day and former important sites and structures such as bridges, tunnels and old stations that may have been abandoned or destroyed during the time. After the construction of a YVR heritage geodatabase, its contents can be shared within a local network or via the Internet so multiple users will be able to modify and utilize it (for example by using an ArcGIS Online server). For this reason, such a geodatabase needs to be user-friendly from the data acquisition phase to the mapping one, not only by 
scholars and specialists but also by the public (LorenMéndez et al., 2018).

\subsubsection{Data acquisition}

The dataset source will include remotely sensed imagery, topographic maps, digital elevation models, on-site survey data, digital historical documents, and topographic and thematic historical maps. Among which, the remotely sensed data for the main cities along the railway can be found from the QuickBird satellite, covering the territory from Kunming to Kaiyuan, Mengzi, Jianshui, Hekou, Laocai, Hanoi and Haiphong. The on-site survey data come from previous research. For example, the architectural study of the railway stations (Fan, 2008), as well as the photos and other video material from fieldworks are available. The historical documents are mainly from the Archives Nationales d'Outre-mer in Aix-en-Provence. In this national archive, the government documents from the French Indochina, including the preliminary survey, finance plan, engineering construction and design maps of the railway works are available in paper forms. The Guimet Museum in Paris and the Railway Museum in Mulhouse (France) saved some historical photos taken by former workers of YVR in Yunnan and Vietnam. The Provincial Archive of Yunnan has collected and saved the historical records from other local museums and has published the book - Historical Compilation of Yunnan-Vietnam Railway. This book provides abundant information on the process of the YVR construction. The Association of the French Souvenir of China (Souvenir Francais de Chine), the French Colonial Companies (Les Entreprises Coloniales Françaises), and French Estates of Indochina (Éts Français de l'Inde) also digitalized some historical photos and collect them in their official websites.

\subsubsection{Data classification and building of geodatabase}

For the large territorial scale of YVR, which extends from southwest of China to the north of Vietnam, the Chinese section is divided into three segments (Kunming-Kaiyuan-Mengzi-Hekou) and the Vietnamese in two segments (Laocai-Hanoi and Hanoi-Haiphong). This division is based on ownership classified by the Railway Bureaus in Yunnan and Vietnam.

Then, for every segment, the data collected can be first organized in vector and raster content categories. Vector data includes polygon, polyline and point features, and their attribute data. The polygons dataset includes features such as the distribution of forest resources, land cover, residential areas and lakes; the polylines dataset contains the rail line itself, current touristic lines, rivers, highway, and other linear features; the points dataset includes the scattered heritage elements as stations, bridges, tunnels, panoramic spots, and the sites where historical photos taken. The information from of historical maps related to this railway have not been studied in former research. In this research, HGIS is meaningful for populating a geodatabase of YunnanVietnam railway: 1) digital raster version of historic map can be georeferenced and analysed within the railway corridor. Geohistorical features that do not exist anymore can be recognized in historical maps and can be digitized in a space-time context. For example, a better understanding of the urban expansion in the railway corridor is possible through a diachronical comparison of the urban areas in different time periods. The analysis of historical written documentation can help in finding the amount of work and funds per section of railway construction and maintenance. Such a kind of historical information can be part of attribute tables related to the railway line vector model, as well as previous research and data collected from site investigation. Using keywords, attribute data can also be related to each other in tables join processes. Figure 2 illustrates the main classification of the data in the proposed Geodatabase of YVR.

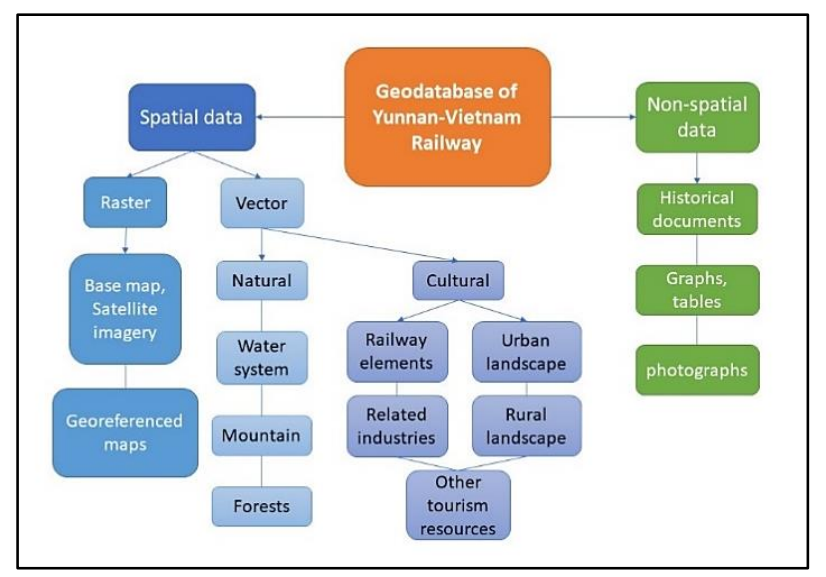

Figure 2. Classification of the data in Geodatabase of YVR.

\subsubsection{Interpretation and function}

After creating and populating the geodatabase, different operations can be performed, such as visualization and display, management and analysis of the data, data overlay and hierarchical browsing, 3D roaming, data retrieval and thematic map customization. The following maps (Figure 3-6) are made based on the geodatabase of YVR that is still a work in progress in this study.

With the help of a GPS tool, the investigated sites can be recorded as a geotagged photo. The photos toolset in ArcGIS is used to input the coordinates of these photos on the map, forming the trail of photos (Figure 3). Then the collected historical photos can be compared with the current photos of the site, applying the methodology of "repeat photography" (Kull, 2005) to analyze its historical changes. 


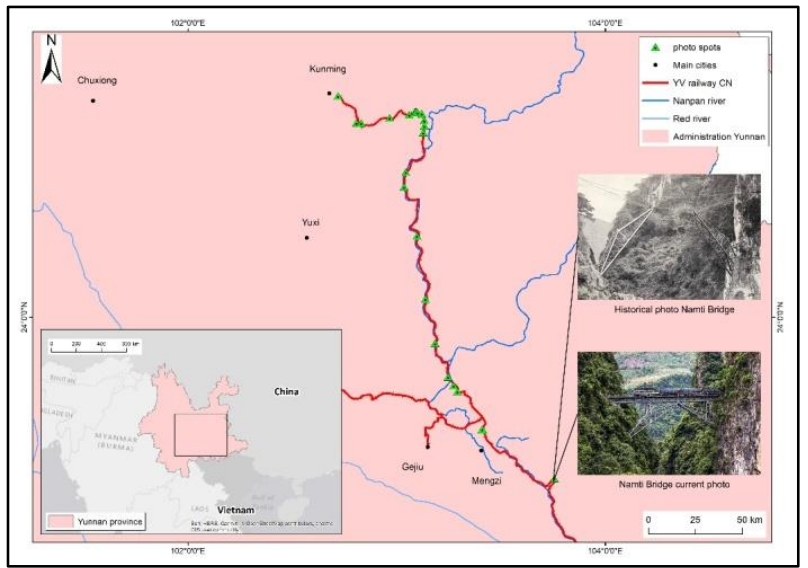

Figure 3. Localization of historical photos.

Figure 4 shows an example of historical maps interpreted in the geodatabase. The base map is made by the English Major H. R. Davies according to the geographic survey during 1894-1900 in Yunnan, which was also one of the earliest maps in Yunnan. After georeferencing, a layer of early developed towns in Yunnan is added in the map, whose attribute table contains the historical records of populations of these towns. These towns are also classified into three classes based on their population size. The emergence of the early towns in Yunnan in the $19^{\text {th }}$ and $20^{\text {th }}$ century followed its development of transportation, namely the YVR as an important factor in promoting its early urbanization.

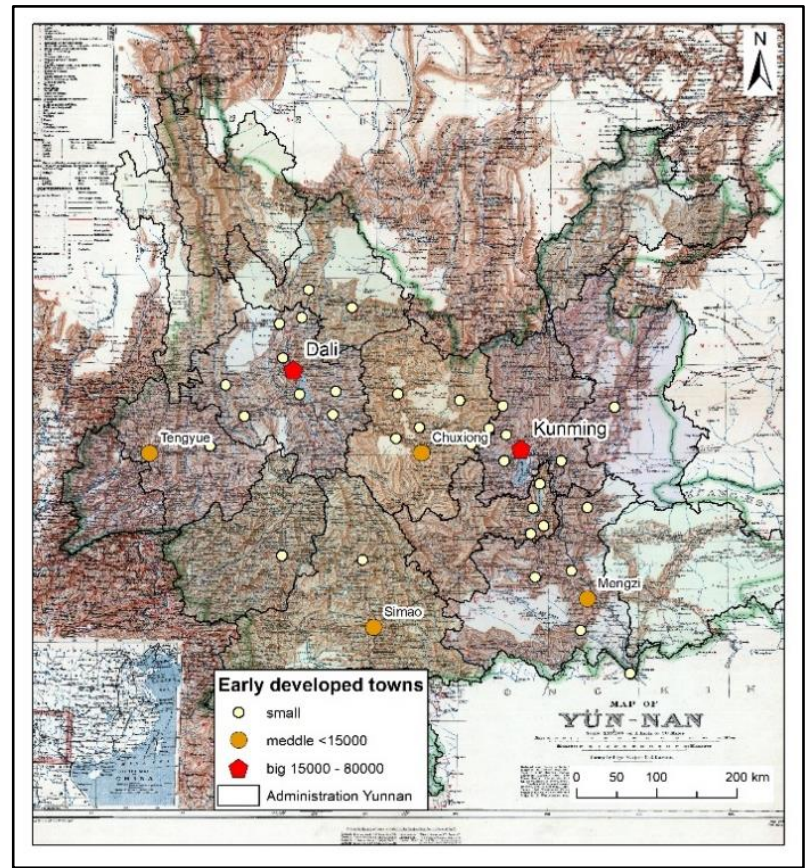

Figure 4. Georeferenced historical map ${ }^{5}$.

After collecting the digital elevation model from an online database of Earthexplorer, further 3D analysis can

\footnotetext{
5 The base map is available in the digital collections of University of Washington Libraries. https://content.lib.washington.edu/
}

be done, such as slope, aspect, and hillshade analysis. Figure 5 shows the slope degree of two areas near Hanoi (left) and Mengzi (right). This analysis allows to clearly visualizing the topographic differences between these two areas and better understands the technical difficulties of constructing the rails on slopes more than $30^{\circ}$.

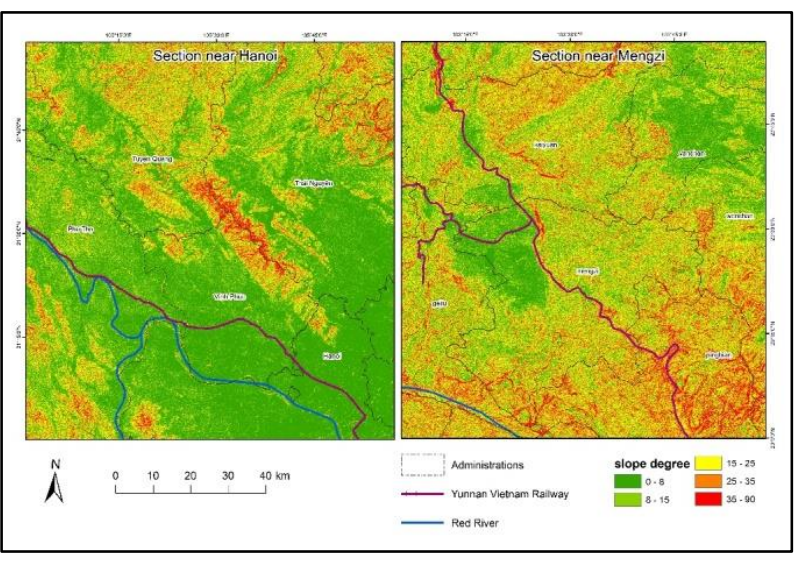

Figure 5. Slope analysis based on DEM.

Figure 6 is an example of map with information of the touristic cities along the railway. In thematic maps, further information of these cities can be interpreted to show their touristic resources and guides for the visitors with different needs.

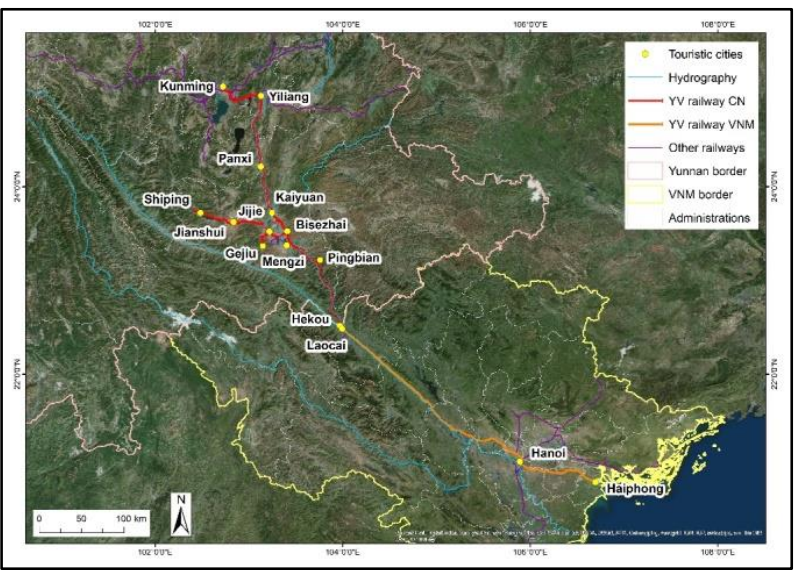

Figure 6. Touristic cities along the railway.

\section{Conclusions}

GIS and other spatial tools are playing an increasing role in the studies and projects of large-scale heritage site like the Yunnan-Vietnam Railway. This article illustrates the process of constructing a Yunnan-Vietnam Railway heritage geodatabase, which will be realized by the stratification of raster, vector data, attribute tables and other data forms. However, this geodatabase is not still completed and work of acquiring data and site investigation keep going on. The establishment of this geodatabase will provide technical support for effective management of all the spatial and non-spatial data related to this railway, quantitative spatial analysis of the railway environment and landscape, as well as the information 
interpretation for the touristic activities, the heritage protection and valorization, and the future regional planning.

\section{Acknowledgments}

This article is written with the financial contribution of the China Scholarship Council.

\section{References}

Archive of Yunnan. (2014). The history of Yunnan province: the construction of railway. Zhuang, X., Wu, Q., \& Li, K (Eds.) Historical compilation of YunnanVietnam railway. pp. 5-17.

Atack, J., Bateman, F., Haines, M. \& Margo, R., A. 2010, Did Railroads Induce or Follow Economic Growth? Urbanization and Population Growth in the American Midwest, 1850-1860, Social Science History, 34(2), 171-197.

Coulls, A. (1999). Railways as world heritage sites. Occasional Papers for the World Heritage Convention. pp. 1-23.

Che, L. (2006). Yunnan - Vietnam Railway and the input of modern science and technology to Yunnan. Journal of Kunming University of Science and Technology, 6 (4), 25-28.

Chen, Z. (2011). Yunnan-Vietnam Railway (Yunnan): Modern Station Building Conservation Research. Kunming University of Technology.

Dann, G. M. (1994). Travel by train: keeping nostalgia on track. Tourism: The state of the art, pp. 775-782.

Fan, Y. (2008). Study on the Railway Stations along the Yunnan-Vietnam Railway (Yunnan Section). Master thesis, Kunming University of Science and Technology.

Fan, Y (2011). An introduction of the development of tourism resources of the Yunnan-Vietnam Railway. Human and inhabitant, (5), 64-65.

Feng, Z. (2016). Study on framework of the protection and GIS technology application of the Sichuan-Tibet "Tea Horse Road" cultural routes heritage. Master thesis, Chongqing University.

Gregory, I.N., \& Healey, R.G. (2007). Historical GIS: structuring, mapping and analysing geographies of the past. Progress in Human Geography, 31(5), 638-653. https://doi.org/10.1177/0309132507081495.

Gao, Q. (2012). The study of analysis method and application in GIS-based greenway planning Master dissertation, Hunnan University. Planners. 1, 318- 322.

Howard, P. (2003) Heritage: Management, Interpretation, Identity. London \& New York: Continuum.

Knowles, A.K. (2000). Introduction. Social Science History, 24 (3), pp. 451-470.

Knowles, A.K. (2008). GIS and History. In Knoles A.K. (ed.) Placing History: How Maps, Spatial Data, and GIS
Are Changing Historical Scholarship. Redlands, CA, ESRI Press, pp. 1-25.

Knowles, A.K., et al. (2008). What Could Lee See at Gettysburg? In Placing History: How Maps, Spatial Data, and GIS Are Changing Historical Scholarship, Redlands, CA, ESRI Press, pp. 235-65.

Knowles, A.K. (2013). A Cutting-Edge Second Look at the Battle of Gettysburg. Retrieved from http://www.smithsonianmag.com/history-

archaeology/A-Cutting-Edge-Second-Look-at-the-

Battle-of-Gettysburg.html.

Kull, C.A. (2005) Historical landscape photography as a tool for land use change research. Norsk Geografisk Tidsskrift - Norwegian Journal of Geography 59:253268.

Luo, J. (2012). Construction of industrial heritage corridor of Yunnan-Vietnam Railway. Master thesis, Yunnan University.

Loren-Méndez, M., Pinzón-Ayala, D., Ruiz, R., \& Alonso-Jiménez, R. (2018). Mapping Heritage: Geospatial Online Databases of Historic Roads. The Case of the N-340 Roadway Corridor on the Spanish Mediterranean. ISPRS International Journal of GeoInformation, 7(4), 134.

Morillas-Torné, M. (2012). Creation of a Geo-Spatial Database to Analyse Railways in Europe (1830-2010).

A Historical GIS Approach. Journal of Geographic Information System, 2012, 4, p. 176-187.

Petrescu, F. (2007). The use of GIS technology in cultural heritage. In Proceedings of the XXI International CIPA Symposium, Athens, Greece. pp. 01-06.

Tang, J. \& Zhao, Y. (2013). Application research of spatial information technology in the protection planning of large-scale linear cultural heritage. Beijing Planning Review, (1), 79-84.

Tang, Y. (2017). Research on the construction of the spatial pattern of the Chinese eastern railway heritage corridor from the perspective of all-for-one tourism. Doctoral dissertation, Harbin Institute of Technology.

Wang, Y. (2011). The traditional regional cultural landscape protection model based on landscape fragmentation analysis - taking Zhifu in Zhuji, Zhejiang Province as an example. Geographical research, 1, 1022.

Zhang, H. (2010). Landscape archaeology: its concept, methodology and practice. Cultural Relics in Southern China, 4, 8-15.

Zhang, L., He Y. \& Liu X. (2010). Discussion on the relationship between the grade setting of the railway stations of Yunnan-Vietnam railway and the urbanization in its surroundings. Yunnan Geographical Environment Research, 22(4), 40-45. 
Zhang, M. (2013). The protection and value of YunnanVietnam Railway. Thinking, S2, 100-101.

Zhan, Q., Guo, H. (2015). Suitability analysis of heritage corridor based on GIS and RS.

Zhang, Y. (2017). Regional landscape from the perspective of linear cultural heritage- taking Beijing, Tianjing and Hebei as an example. Master thesis, Tianjing University in China. 